\title{
Constructed floating wetlands made of natural materials as habitats in eutrophicated coastal lagoons in the Southern Baltic Sea
}

\author{
Svenja Karstens ${ }^{1}$ (i) $\cdot$ Maria Langer $^{1} \cdot$ Hayato Nyunoya ${ }^{2} \cdot$ leva Čaraite $^{1} \cdot$ Nardine Stybel $^{1}$. \\ Arturas Razinkovas-Baziukas ${ }^{3} \cdot$ Ralf Bochert $^{4}$
}

Received: 14 September 2020 / Revised: 27 April 2021 / Accepted: 28 April 2021 / Published online: 6 July 2021

(c) The Author(s) 2021

\begin{abstract}
Eutrophication remains an environmental challenge in lagoons along the Southern Baltic Sea. Floating islands planted with emergent macrophytes are an option to remove nutrients from eutrophicated waters. Furthermore, floating wetlands offer other ecosystem services such as the provision of habitats. Numerous scientific studies have been conducted; however most remain on the laboratory scale. This research explores the challenges associated with installations in coastal environments and focuses on sustainability of the island design, the habitat function as well as nutrient removal. Most floating wetland designs use polyethylene, polypropylene, polyurethane or polyvinyl alcohol foam to ensure the buoyancy. For this study an artificial polymer free island design was developed and tested. The floating constructions in the Darss-Zingst-Bodden-Chain were planted with native macrophytes which have the potential to act as 'biodiversity-supplements' to the adjacent coastal wetlands: Bolboschoenus maritimus, Carex acutiformis, Iris pseudacorus, Juncus effesus, Lythrum salicaria, Schoenoplectus lacustris, Typha latifolia. The chosen macrophytes survived fluctuating salinities. After three months the above-ground biomass was harvested and analyzed for the nutrient concentrations. Phosphorus concentrations were highest in L. salicaria and nitrogen in I. pseudacorus. Video monitoring and field observations were applied in order to observe animals. Birds did not use the floating wetlands as breeding grounds, but the grey heron (Ardea cinerea) was a common visitor for foraging. Especially surprising was the large amount of juvenile eels (Anguilla anguilla). A diverse and large root network below the floating islands boosts not only nutrient removal but serves as a shelter and refuge for fish such as the endangered eel.
\end{abstract}

Keywords Floating wetlands $\cdot$ Eutrophication $\cdot$ Biodiversity $\cdot$ Environmental remediation $\cdot$ Baltic Sea

Svenja Karstens

karstens@eucc-d.de

1 EUCC - Coastal Union Germany, Technologiezentrum Warnemünde, Friedrich-Barnewitz-Straße 3, 18119 Rostock, Germany

2 Department of Bioscience and Biotechnology, Kyushu University, 744 Motooka, Nishi-ku, Fukuoka 819-0395, Japan

3 Klaipeda University, Herkus Mantas str. 84, 92294 Klaipėda, Lithuania

4 Mecklenburg-Vorpommern Research Centre for Agriculture and Fisheries (LFA MV), Institute of Fisheries, Südstr. 8, 18375 Born, Darß, Germany

\section{Introduction}

As a result of the last glacial period and subsequent postglacial processes the coast of the Baltic Sea is fragmented with many shallow, semi-enclosed water bodies (Hupfer 2010). These lagoons are particularly prone to eutrophication due to reduced water exchange with the open sea and human pressures such as intensive agriculture in the hinterland or wastewater discharges (Kautsky and Kautsky 2000; Conley et al. 2011; Newton et al. 2014). In-sea measures in addition to drainage basin based mitigation measures are required to achieve the good ecological status required by the European Water Framework Directive and the Marine Strategy Framework Directive (Karstens et al. 2018). Floating wetlands are presented as an effective ecological engineering tool to remove nutrients from eutrophicated waters (e.g. White and Cousins 2013; West et al. 2017; Bi et al. 2019). This 'phyto-technology', 
where emergent macrophytes grow on a buoyant platform and adsorb nutrients such as phosphorus and nitrogen directly from the water, has gained increasing attention in recent years (Colares et al. 2020). Harvest of aboveground biomass can remove assimilated nutrients directly from the system. In addition, floating wetlands attenuate wave energy and water flow and are consequently able to enhance particle settling and nutrient burial (Pavlineri et al. 2017). Macrophyte root-associated denitrification is another important nitrogen removal pathway (Choudhury et al. 2019). Floating wetlands shade the water and influence thereby the water temperature and sunlight availability for algal growth (Borne 2013; Pavlineri et al. 2017). Furthermore, floating wetlands offer other ecosystem services such as the provision of habitats or littoral zone protection (Yeh et al. 2015). They serve as a refuge for aquatic species (e.g. Nakamura et al. 1998; Huang et al. 2017) or offer alternative nesting habitats for birds (e.g. Hancock 2000; Shealer et al. 2006; DeSorbo et al. 2008; Nummi et al. 2013; Overton et al. 2015).

Removal efficiencies of floating wetlands for nutrients have been studied extensively, but most remain on a mesocosm-scale (e.g. Bu and Xu 2013; Chang et al. 2012; Cao et al. 2016; Geng et al. 2017), only a few were conducted in-situ (e.g. Wang et al. 2015; Olguín et al. 2017; Afzal et al. 2019) and even fewer in saline environments (e.g. Sanicola et al. 2019). Also Colares et al. (2020) conclude in their comprehensive review and bibliometric analysis that although floating wetlands have been employed all over the world, most studies remain on laboratory or pilot scale. The authors argue that the main challenge is to apply floating wetlands on a more realistic setting and to monitor macrophyte and floating carrier behavior in the natural environment, which is more aggressive than laboratory conditions. Much work has to be carried out prior to the practical installations of floating wetlands in coastal waters to understand the legal permit process and to find suitable installation sites (Karstens et al. 2018). In 2018, first floating wetlands in brackish coastal waters were installed and led to the question how the floating constructions and macrophytes perform under year-round conditions in real environments. The objectives of this study were to (a) determine nutrient concentration in different plant species grown on floating wetlands; (b) identify year-round environmental conditions; and (c) evaluate the utilization of floating islands has habitats.

\section{Materials and methods}

\section{Installation site and macrophyte choices}

Floating wetlands in brackish waters were installed in the Darss-Zingst-Bodden-Chain in Germany in May 2018
(54 22'47.9'” 12 $\left.31^{\circ} 26.4^{\prime \prime} \mathrm{E}\right)$. The Darss-Zingst-BoddenChain is a shallow lagoon system with a mean water depth of $2 \mathrm{~m}$ and only a narrow outlet to the Baltic Sea (Schumann et al. 2006). Hence, water exchange between the open Baltic Sea and the Bodden is low and induced meteorologically with inflow situations under strong and persistent northeasterly winds (Selig et al. 2007). The long water residence time makes the lagoon particularly prone and vulnerable to eutrophication. Furthermore, the Darss-Zingst-BoddenChain faces various anthropogenic pressures including inter alia agriculture and tourism. Although nutrient input decreased, the Darss-Zingst-Bodden-Chain is still strongly eutrophic (Selig et al. 2007; Berthold and Schumann 2020). The installation site is within the national park 'Vorpommersche Boddenlandschaft' ('Western Pomerania Lagoon Area').

Similar to most lagoons along the Southern Baltic Sea, the coastal wetlands of the Darss-Zingst-Bodden-Chain are dominated by Phragmites australis (Berthold et al. 2018; Karstens et al. 2019). Reed tends to form near monocultures and potentially limits biodiversity at the landscape scale (Prach and Pyšek 1994; Wanner 2009; Sweers et al. 2013). For this study we chose wetland plants that were mapped close to the installation site and offer a chance to act as biodiversity supplements to the reed wetlands (www.umwel tkarten.mv-regierung.de). Following macrophyte species were chosen: Bolboschoenus maritimus, Carex acutiformis, Iris pseudacorus, Juncus effesus, Lythrum salicaria, Schoenoplectus lacustris, Typha latifolia. All plants are native, non-invasive species able to thrive in hydroponic environments. Besides the nutrient removal efficiency, we aimed at local ecosystem integrity (see also Pavlineri et al. 2017). Macrophyte species were pre-cultivated on coir mats and planted on the islands in May 2018.

\section{Floating construction design}

Existing floating constructions for emergent macrophytes are manufactured mostly from artificial materials, like polyethylene, polypropylene, polyurethane or polyvinyl alcohol foam (Table 1). This is congruent to findings by Wang et al. (2020): The authors reviewed the main component elements of ecological floating beds applied in scientific studies and none were without artificial polymers.

In order to avoid artificial polymers completely and to offer a habitat made out of local natural materials, two floating wetlands were developed specifically for this study by Ökon Vegetationstechnik GmbH. The islands consisted of an enveloping stainless steel net filled with native dry reed stems (P. australis). Each hexagon shaped island had a size 
Table 1 Selection of companies offer floating wetlands - results of web search (This overview is not exhaustive - Keywords such as "constructed floating wetland', 'floating treatment wetland', 'floating ecological bed', 'Röhrichtinsel' (German), 'Schwimminsel' (German), 'radeaux végétalisés' (French), 'structures flottantes + végétation' (French), 'humedal flotante' (Spanish) were used for the web search)

\begin{tabular}{lll}
\hline Company & Country & Material \\
\hline AquaBiofilter & Australia & Polyuethane foam (PU) \\
Aquaterra Solutions & France & Polyethylene (PE) \\
Beemats & USA & Polyvinyl alcohol foam (PVA) \\
BGS Ingenieurbiologie Vegetationstechnik & Germany & $\begin{array}{l}\text { Polyethylene (PE), polypropylene (PP), } \\
\text { polyurethane foam (PU) }\end{array}$ \\
Biomatrix & Scotland & Thermo fused high-density polyethylene (PE) \\
Blue Mater & Portugal & Cork \& polyurethane paste (PU) \\
Frog Environmental BioHaven & USA/UK & Polyurethane foam (PU) \\
Marcanterra & France & Wood \& cork \\
Ökon-Vegetationstechnik & Germany & Stainless steel \& reed stemsThermowood \\
Rhizotech & Germany & Polyurethane foam (PU) \\
Spel environmental integrated water solutions & Australia & Recycled polyethylenterephthalat (PET) \\
Terrapin Water & Canada & High density polyethylene (HDPE) \\
Veg Tec & Sweden & Polyethylenterephthalat (PET) \\
\hline
\end{tabular}

of $3.5 \mathrm{~m}^{2}$ allowing modular enlargement. The reed stems provided buoyancy, also served as rooting substrate for the plants and settlement area for microorganisms (Fig. 1). The installation was carried out in May 2018 from a floating jetty and floating wetlands are located close to the shore.

\section{Field work and laboratory analysis}

Environmental conditions at the installation site were monitored. Data on daily water level fluctuations and ice cover were obtained from the national waterways and shipping office. Prior to installations (April), during the vegetation peak (June and July) and at the harvest time (September), water $\mathrm{pH}$, dissolved oxygen and water temperature were measured at $10 \mathrm{~cm}$ depth in situ at two sampling sites monthly with a multiparametric probe (Hach-Lange). For dissolved nutrient analysis, water samples ( $n=3$ per site) were filtered. Dissolved nitrites $\left(\mathrm{NO}_{2}{ }^{-}\right)$, combined nitrites and nitrates $\left(\mathrm{NO}_{\mathrm{x}}{ }^{-}\right)$and inorganic phosphorus (DIP) concentrations in filtered water samples were measured using standard colorimetric methods with a 4-channel continuous flow analyzer ( $\mathrm{San}^{++}$, Skalar) (Grasshoff et al. 1983). $\mathrm{NO}_{3}{ }^{-}$concentrations was calculated as a difference between $\mathrm{NO}_{\mathrm{x}}{ }^{-}$and $\mathrm{NO}_{2}{ }^{-}$, Dissolved $\mathrm{NH}_{4}{ }^{+}$was determined using nitroprussiate as a catalyst by the salicylate-hypochlorite method (Bower and Holm-Hansen 1980). Total nitrogen (TN) was determined applying high temperature $\left(680{ }^{\circ} \mathrm{C}\right)$ combustion catalytic oxidation/NDIR method using a Shimadzu TOC V-CPH analyzer equipped with a TN module. Total phosphorus (TP) was quantified spectrophotometrically with the molybdate method (Koroleff 1983) after digestion and oxidation of the organic $P$ forms with alkaline peroxodisulphate acid (see also Vybernaite-Lubiene et al. 2017).

All aboveground biomass was cut on the 6th of September 2018 and directly transported to the laboratory for further analyses. Plant material was dried for $24 \mathrm{~h}$ at $60{ }^{\circ} \mathrm{C}$, milled and homogenized. Three replicates per species were then analyzed for phosphorus (ICP-OES) and nitrogen (Kjeldahl method) concentrations (for more information on methods see VDLUFA
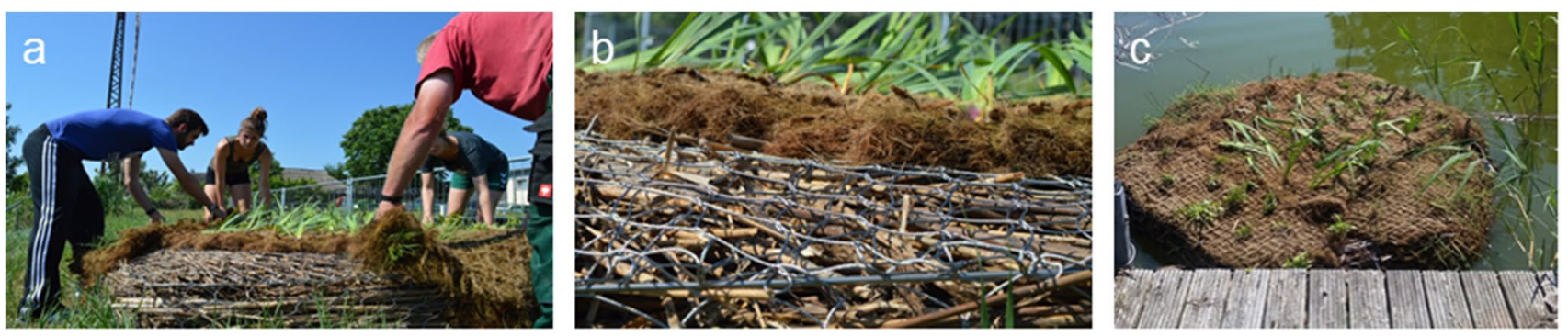

Fig. 1 Installation of first floating wetlands. (A) Pre-cultivated coir mats with macrophytes were placed on the buoyant structure. (B) The carrier consists of an enveloping stainless steel net filled with native dry reed stems. (C) Installation was carried out from a jetty 
III 4.1.1 and VDLUFA III 10.8.2). All data analyses were performed and all figures were prepared using the open-source statistical software R (version 3.6.3).

\section{Monitoring habitat function}

Continuous video monitoring was applied on one of the floating wetlands with a HDR time-lapse camera (TLC200 Pro $B R I N N O)$ in order to observe larger animals visiting. The camera (sensor type $1 / 3$ " HDR, dynamic range $115 \mathrm{db}, 1.3$ megapixels, AVI $1280 \times 720 \mathrm{p}$ ) was set $2.5 \mathrm{~m}$ in front of the floating wetland and could cover the whole area. Pictures of the island were taken every ten minutes between the 31 st of May 2018 and the 6th of September 2018. Video analysis was carried out manually for the whole daytime from sunrise to sunset when camera system switched on and off automatically during these three months with VLC media player (VideoLAN). Pictures where animals could be identified were stored separately in order to distinguish the different species. Insects could not be detected using the video material.

In addition to the camera monitoring, field observations were carried out during the harvest of emergent macrophytes when the islands were removed from the water. The harvest took place on the 6th of September 2018 and islands were taken out of the water. Eels inside and on the islands were semi-quantitatively collected, counted and released. Recognizable macroorganisms like crustaceans, molluscs and insects were determined after taking photos.

\section{Results}

\section{Floating wetland performance and environmental conditions}

All chosen macrophytes grew well under brackish water conditions and fluctuating salinities although $C$. acutiformis, I. pseudacorus and J. effesus are not salt tolerant according to Ellenberg and Leuschner (2010). Nutrient concentrations differed significantly between plant species (Figs. 2 and 3). Mean phosphorus concentrations ranged between $0.5 \mathrm{~g} \mathrm{~kg}^{-1}$ dry mass in $B$. maritimus and up to $1 \mathrm{~g} \mathrm{~kg}^{-1}$ dry mass in L. salicaria. Mean nitrogen concentrations were between $1.3 \%$ of dry mass in S. lacustris and $2 \%$ of dry mass in $I$. pseudacorus.

Fluctuations of water level (Fig. 4) and salinity (Table 2) at the installation site depend on in/outflow from the open Baltic Sea into the lagoon. Total

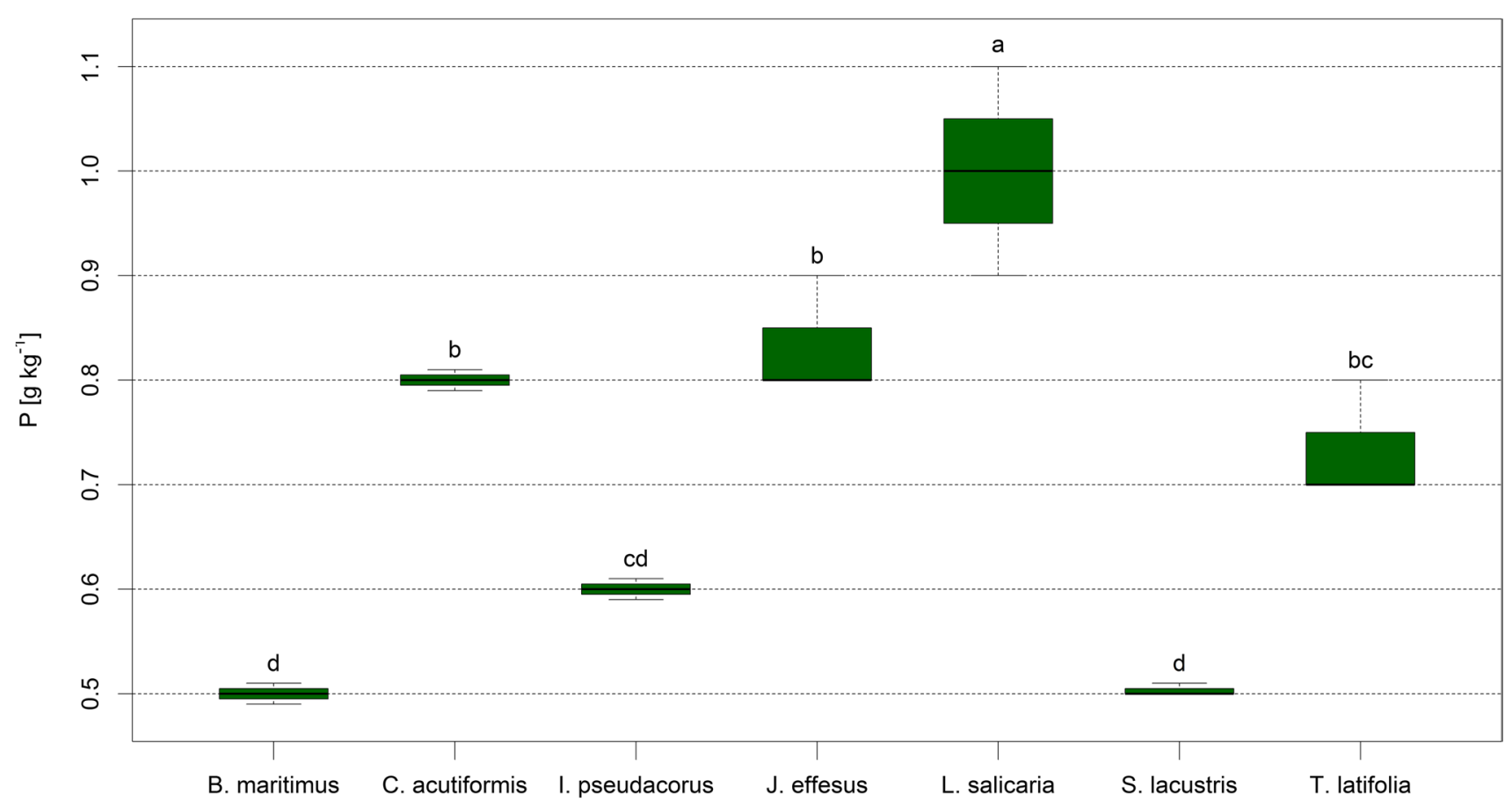

Fig. 2 Phosphorus $\left[\mathrm{g} \mathrm{kg}^{-1}\right.$ dry mass] in aboveground plant biomass in the seven different macrophytes species during harvest time in September 2018. Letters above the boxplots represent the results of post-hoc comparisons of group means with Tukey's honest significant differences test $(p<0.05)$ which were conducted between all plant species ( $n=3$ per species). L. salicaria (a) has significantly higher phosphorus concentrations than all other plant species (letters $b-c$ $-\mathrm{d})$ 


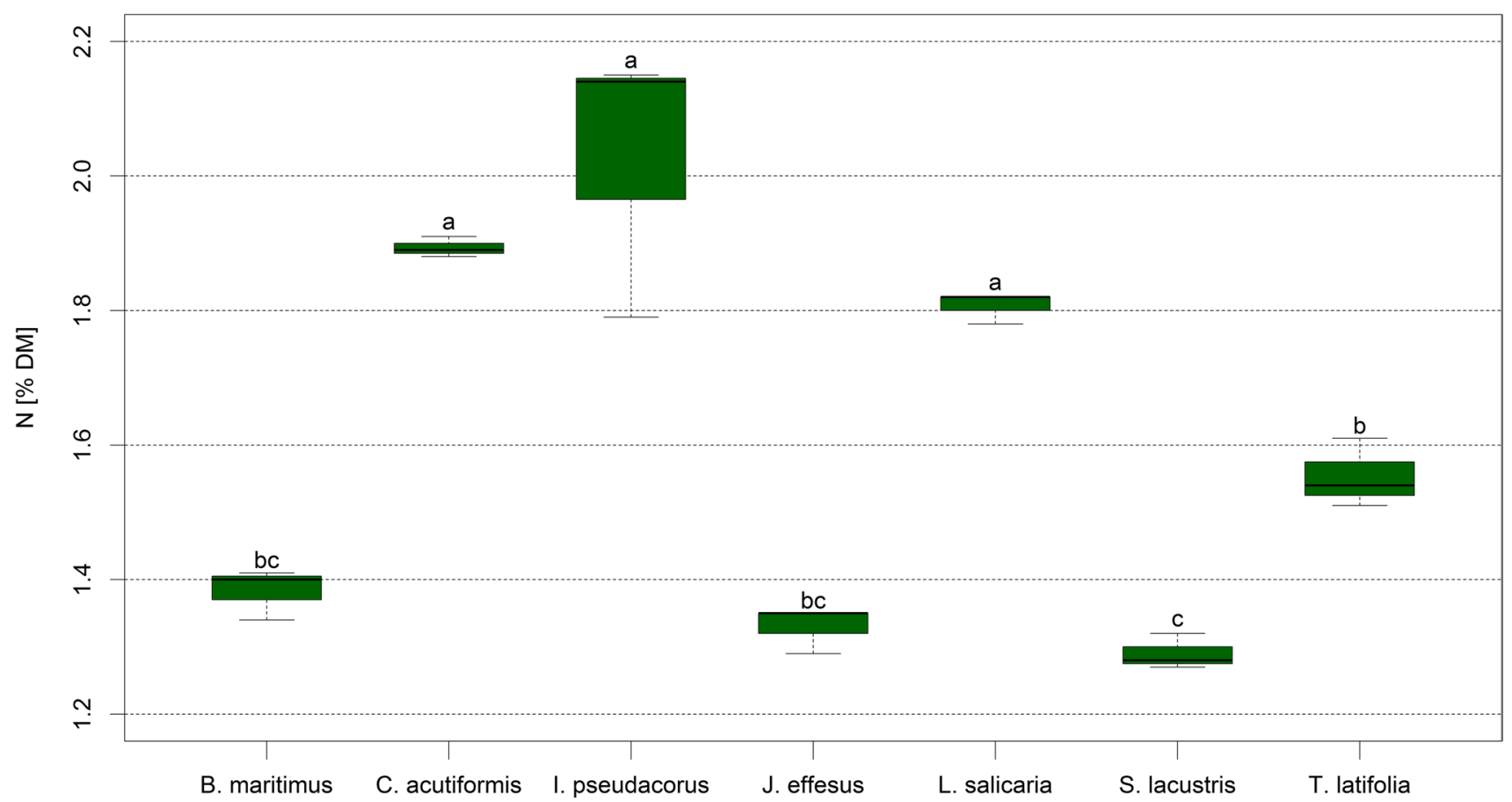

Fig. 3 Nitrogen [\% of dry mass] in aboveground plant biomass in the seven different macrophytes species during harvest time in September 2018. Letters above the boxplots represent the results of post-hoc comparisons of group means with Tukey's honest significant differ- ences test $(\mathrm{p}<0.05)$ which were conducted between all plant species ( $\mathrm{n}=3$ per species). Although I. pseudacorus (a) has the highest nitrogen concentrations, the difference is not significant compared to nitrogen in C. acutiformis or L. salicaria (both also letter a)

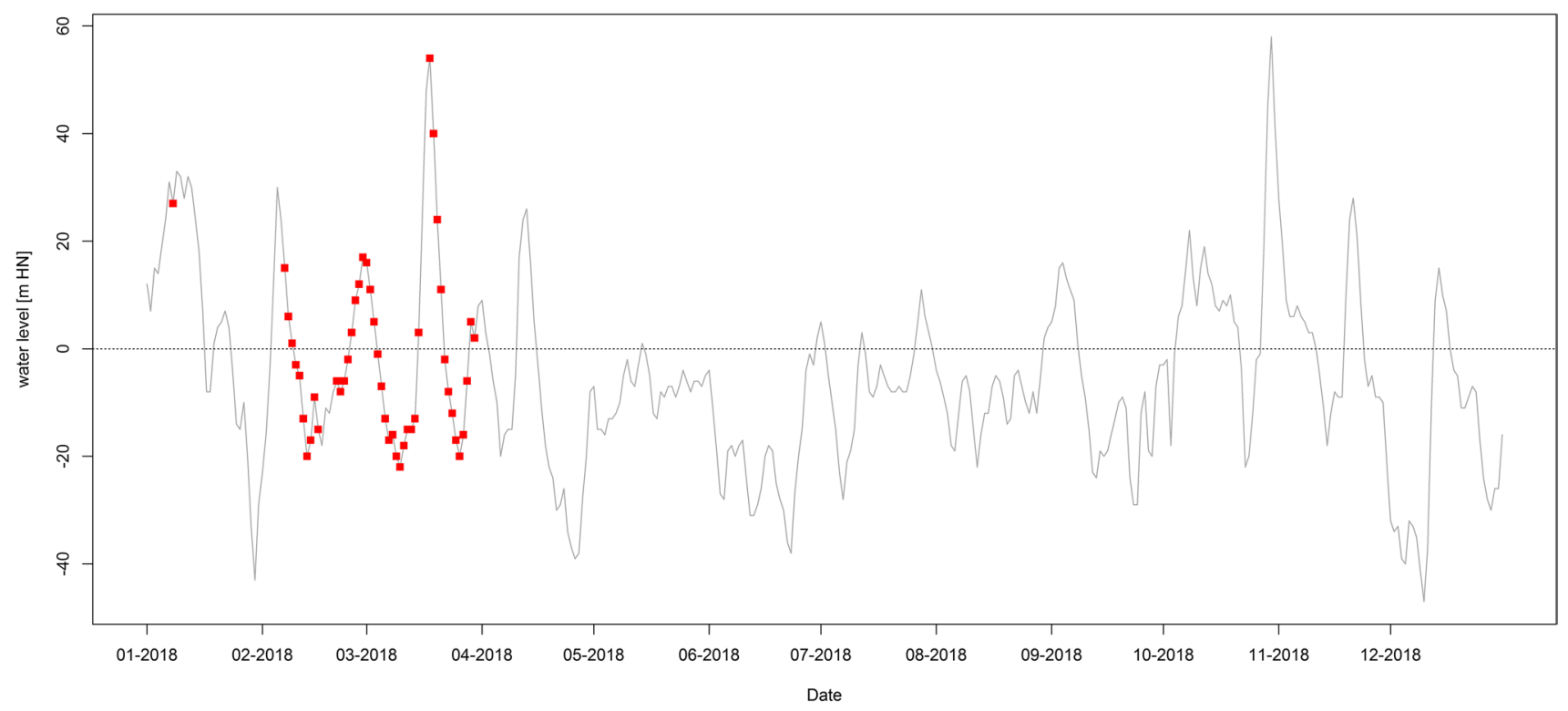

Fig. 4 Water level fluctuations at Althagen $\left(54^{\circ} 22^{\prime} 11.3^{\prime \prime} \mathrm{N}\right.$ $\left.12^{\circ} 24^{\prime} 56.6^{\prime \prime} \mathrm{E}\right)$, close to the installation site. Red points show days with ice influence. Ice cover, side ice or ice drift occurred on 47 days in 2018 (Data derived from the waterways and shipping office - Was- serstraßen- und Schifffahrtsverwaltung des Bundes (WSV), Bundesanstalt für Gewässerkunde (BfG), https://www.pegelonline.wsv.de/ webservices/files/Wasserstand+Rohdaten/OSTSEE/ALTHAGEN) 
Table 2 Environmental conditions at the installation site: Temperature $\left({ }^{\circ} \mathrm{C}\right), \mathrm{pH}$, oxygen saturation (\%), salinity (PSU) as well as mean values of ammonium, nitrite, nitrate, total nitrogen, dissolved inor- ganic phosphorus and total phosphorus (all in $\mu$ mol $1^{-\mathbf{1}}$ ). First samples were taken before floating wetland installations and last samples were taken on the harvest day

\begin{tabular}{|c|c|c|c|c|c|c|c|c|c|c|}
\hline Date & $\mathrm{T}$ & $\mathrm{pH}$ & $\mathrm{O}_{2}$ & Salinity & NH4+ & NO2- & NO3- & $\mathrm{TN}$ & DIP & TP \\
\hline 24.04 .2018 & 13.1 & 9.0 & 81.8 & 2.8 & 20.5 & 3.0 & 105.6 & 325.0 & 1.4 & 6.3 \\
\hline 14.06.2018 & 18.3 & 9.1 & 91.7 & 2.4 & 6.5 & 0.3 & 26.8 & 205.9 & 1.1 & 4.6 \\
\hline 06.07.2018 & 20.8 & 8.3 & 91.6 & 2.8 & 4.6 & 0.3 & 6.9 & 171.2 & 1.2 & 4.4 \\
\hline 06.09 .2018 & 19.6 & 7.5 & 96.7 & 3.7 & 0.8 & 0.3 & 43.3 & 227.6 & 0.6 & 4.5 \\
\hline
\end{tabular}

phosphorus concentrations in the water ranged between 4.1-6.4 $\mu \mathrm{mol} 1^{-1}$ and total nitrogen concentrations between 157 and $351 \mu \mathrm{mol} 1^{-1}$. Except for the dissolved inorganic phosphorus, nutrient concentrations were significantly higher in April than June, July or September (Fig. 5). Nitrate concentrations went up to $107 \mu \mathrm{mol}^{-1}$ in spring and down to a minimum of
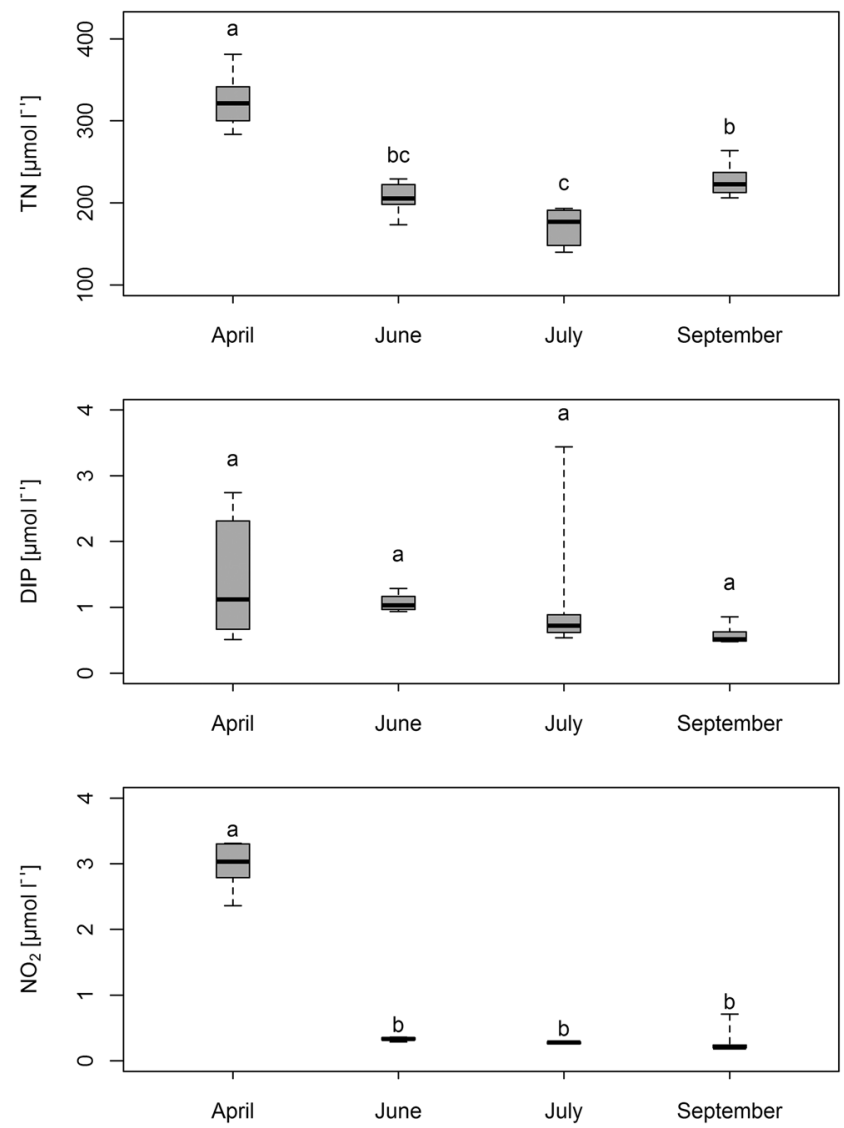

Fig. 5 Nutrient concentrations in the water: Total nitrogen (TN), total phosphorus (TP), dissolved inorganic phosphorus (DIP), ammonium $(\mathrm{NH} 4+)$, nitrite $\left(\mathrm{NO}_{2}{ }^{-}\right)$and nitrate $\left(\mathrm{NO}_{3}{ }^{-}\right)$. Letters represent the
$5 \mu \mathrm{mol} \mathrm{l}^{-1}$ in July when biomass development peaks. Environmental conditions at the installation site can be harsh; however, ice cover or ice drift occurred only prior to installations (Fig. 4). Nevertheless, the margins of the floating wetlands started drowning at the End of August 2018 and biomass development was influenced thereby (Table 3 ).
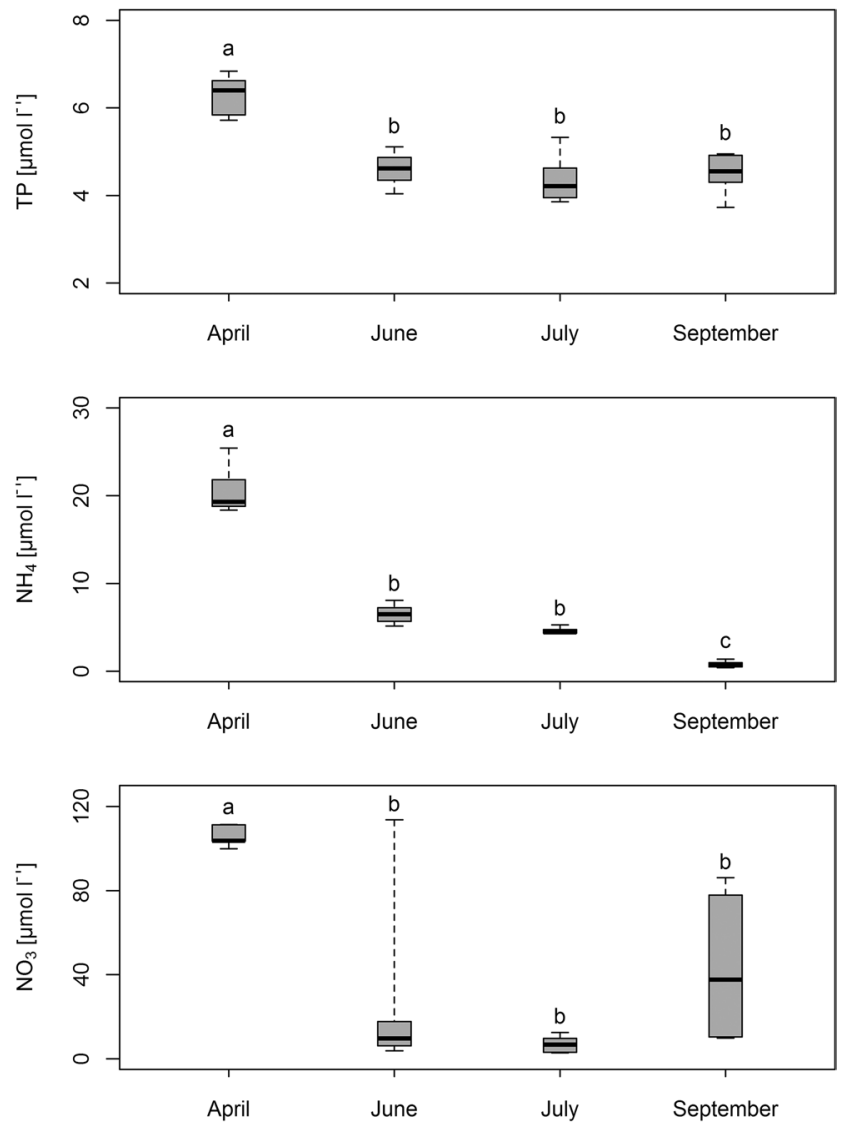

results of post-hoc comparisons of group means with Tukey's honest significant differences test $(p<0.05)$ which were conducted between all plant species ( $n=6$ per sampling date) 
Table 3 Mean phosphorus (P) and nitrogen $(\mathrm{N})$ concentration in harvested above-ground biomass. Biomass development was influenced by the drowning of the island margins in late August 2018 and does not represent optimal plant growth. Therefore biomass $\left[\mathrm{kg} \mathrm{m}^{-2}\right]$ and nutrient stocks are displayed in grey

\begin{tabular}{|c|c|c|c|c|c|}
\hline & $\begin{array}{l}\text { Biomass } \\
{\left[\mathrm{kg} \mathrm{m}^{-2}\right]}\end{array}$ & $\begin{array}{c}\mathrm{P} \text { concentrations } \\
{\left[\mathrm{g} \mathrm{P} \mathrm{kg}^{-1}\right]}\end{array}$ & $\begin{array}{l}\text { P stocks } \\
{\left[\mathrm{mg} \mathrm{m}^{-2}\right]}\end{array}$ & $\begin{array}{c}\mathrm{N} \text { concentrations } \\
{[\%]}\end{array}$ & $\begin{array}{l}\mathrm{N} \text { stocks } \\
{\left[\mathrm{mg} \mathrm{m}^{-2}\right]}\end{array}$ \\
\hline Bolboschoenus maritimus & 0.22 & 0.50 & 109 & 1.38 & 3024 \\
\hline Carex acutiformis & 0.16 & 0.80 & 128 & 1.89 & 3038 \\
\hline Iris pseudacorus & 0.40 & 0.60 & 242 & 2.03 & 8188 \\
\hline Juncus effesus & 0.24 & 0.83 & 204 & 1.33 & 3255 \\
\hline Lythrum salicaria & 0.25 & 1.00 & 247 & 1.81 & 4462 \\
\hline Schoenoplectus lacustris & 0.14 & 0.50 & 68 & 1.29 & 1742 \\
\hline Typha latifolia & 0.34 & 0.73 & 250 & 1.55 & 5306 \\
\hline
\end{tabular}

\section{Utilization of floating wetlands as habitats}

Birds visited the monitored floating wetland on 47 out of 99 monitored days (48\%). While the grey heron (Ardea cinerea) visited the island on 45 days, other bird species were rarely seen. Twice gulls (Chroicocephalus ridibundus) were observed on the island (3rd of July, 9:34 am, 15th of August 2018, $9.03 \mathrm{am}$ ). Furthermore, each of the following species were observed only once: blackbird (Turdus merula, 26th of June, 6:22 pm), mallard (Anas platyrhynchos, 14th of July, 6:47 am) and sparrow (Passer indet., 23rd of July). The island was not used as a breeding ground by any bird. No grazing was observed. The mean resting time of the grey herons on the island was $36 \pm 44$ min (Fig. 6). Twice the camera could capture a grey heron hunting directly from the island into the water (8th of July, 5:07 am, 29th of July, 03:48 am), the other photos showed the bird foraging or resting (Fig. 7B). We divided the days into three categories: "sunrise" (3:30-6:30 am), "sunset" (7-10 pm) and "other". In $75 \%$ the grey heron stayed during sunrise on the floating wetland (Fig. 6). Besides birds, common water frog (Rana esculenta) (e.g. 4th of August, 2:12 pm) and grass snake (Natrix natrix) (e.g. 27th of July, 11:01 am) were detected.

In addition, we could observe fish, crustacean, molluscs and insects when the islands were taken out of the water for macrophyte harvesting (6th of September). We were surprised by the large number of juvenile eels (Anguilla anguilla) hidden inside and on the islands (Fig. 7A). A total of 15 juvenile eels was counted, which would be 2.1 eels per $\mathrm{m}^{2}$. Some eels may have already escaped while the floating wetlands were taken out of the water, thus the real number of eels inside the islands was probably higher. Furthermore, following animals were observed on the floating wetlands: Shrimps (Palaemon
Fig. 6 (A) Daytime of stay and (B) length of stay of the grey heron on the floating wetland
A)

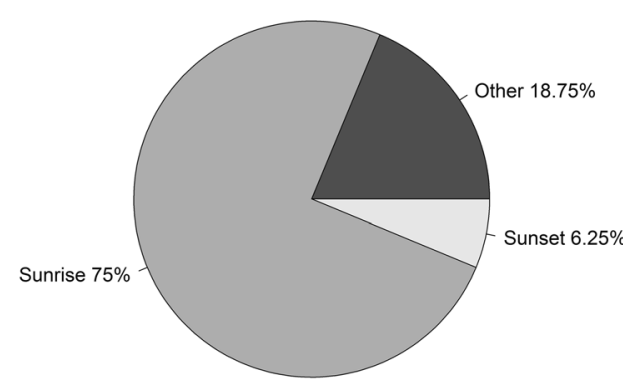

B)

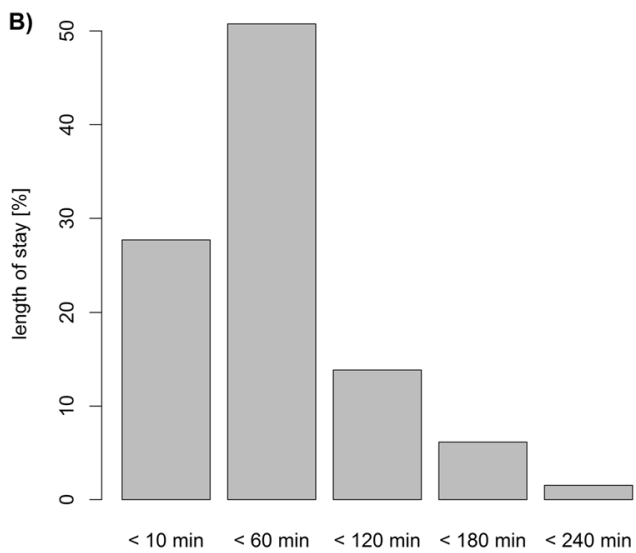



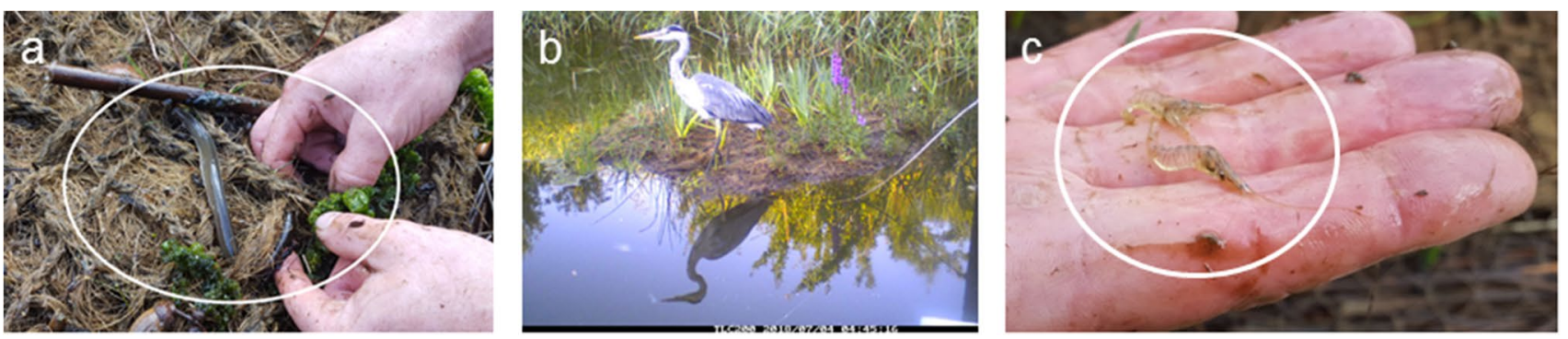

Fig. 7 (A) Juvenile eels used the floating wetlands and the dense root network as a refuge. (B) Grey herons visited frequently, mostly during sunrise. (C) Shrimp also used the floating wetlands as habitats and represent potential food for the grey heron

adspersus), water scorpions (Nepa sp.), crabs (Rhithropanopeus harrisii), snails (Gastropoda indet.) as well as snail spawn. A list of observations can be found in the Appendix Table 5. Table 4 shows the approximate flowering time of the different macrophyte species and overlapping with potential oviposition and breeding times of observed animals.

\section{Discussion}

\section{Biodiversity and remediation of eutrophication}

Common reed (P. australis) usually dominates the coastal wetlands along the lagoons of the Southern Baltic Sea and often inhibits development of other wetland vegetation (Jeschke 1987). Mechanical control (Chambers et al. 1999) or water buffalo grazing (Sweers et al. 2013) are options to regulate reed expansion. However, once interventions stop, reed beds quickly re-establish resulting in a loss of biodiversity and habitats (Esselink et al. 2000; Rannap et al. 2004; Burnside et al. 2007; Wanner 2009). Floating wetlands with a variety of native macrophytes can offer additional habitats as supplement to the adjacent wetlands. An advantage of floating wetlands with a mixture of plants instead of monocultures is that they are less susceptible to seasonal changes and disturbances and offer more biodiverse microbial populations (Zhang et al. 2010; Qiu et al. 2011; Hernández-Crespo et al. 2016). I. pseudacorus was the only plant species protected under the national law (BArtSchV). More endangered native species such as Salicornia europaea, Centaurium littorale or Aster tripolium could also potentially be used.

Total phosphorus and nitrogen as well as ammonium, nitrite and nitrate concentrations in the water were highest in April prior to installations and decreased during summer. However, measurements in the water column are

Table 4 Flowering time of the different macrophyte species (dark grey) and potential oviposition/breeding time of observed animals that could use therefore the floating wetlands (light grey)

\begin{tabular}{|l|l|l|l|l|l|l|}
\hline & April & May & June & July & August & September \\
\hline Bolboschoenus maritimus & & & & & & \\
\hline Carex acutiformis & & & & & & \\
\hline Iris pseudacorus & & & & & & \\
\hline Juncus effesus & & & & & & \\
\hline Lythrum salicaria & & & & & & \\
\hline Schoenoplectus lacustris & & & & & & \\
\hline Typha latifolia & & & & & & \\
\hline Natrix natrix & & & & & & \\
\hline Nepa spec. & & & & & & \\
\hline Gastropoda indet. & & & & & & \\
\hline Chroicocephalus ridibundus & & & & & & \\
\hline Anas platyrhynchos & & & & & & \\
\hline
\end{tabular}


only 'snapshots' and cannot portray any effect of floating wetlands on the nutrient dynamics at the installation site. In contrast, nutrients accumulated in the harvested plant biomass can be regarded as a reliable data on the removal of nitrogen and phosphorus. Nitrogen concentrations were highest in I. pseudacorus, although the plant flowers already between May-June and the island were installed too late for the best possible development. At the harvest time, translocation of nutrients into the rhizome presumably already started. However, nitrogen and phosphorus concentrations were still comparable to floating wetland mesocosm experiments by Keizer-Vlek et al. (2014): 0.6 vs $0.86 \mathrm{~g} \mathrm{P} \mathrm{kg}^{-1} \mathrm{DM}$ and 20 vs $14 \mathrm{~g} \mathrm{~N} \mathrm{~kg}^{-1}$ $\mathrm{DM}$ in the beginning of September in our study and at the end of August in the mesocosm experiments. Wu et al. (2011) compared nutrient uptake of $I$. pseudacorus with other wetland plants and showed their high capacity for nutrient removal. L. salicaria still flowered shortly before harvest time and had the highest phosphorus concentrations. Strategic harvest of macrophytes increases nutrient removal efficiencies (Bi et al. 2019). Harvest before the start of senescence and nutrient translocation into rhizomes is highly recommended. The poales $B$. maritimus and $S$. lacustris had the lowest nutrient concentrations. While the salinity might have been too low at the installation site for $B$. maritimus to thrive, the early flowering time in June-July of S. lacustris could be the reason for the low nutrient concentrations. Harvest during vegetation peak would increase the nutrient removal efficiency as phosphorus and nitrogen concentrations in the aboveground plant tissue would be higher. However, summer harvest contradicts with national nature protection laws (BNatSchG §39) and special permits would be needed. We therefore chose the beginning of September as a compromise, where nutrient concentrations in the aboveground biomass are still relatively high but the breeding season is already over (see Table 4).

Similar floating wetlands in the Curonian Lagoon (Lithuania) with also a mix of Carex acutiformes, Schoenoplectus lacustris and Typha removed $10.3 \mathrm{~g} \mathrm{~N} \mathrm{~m}^{2}$ and $0.5 \mathrm{~g} \mathrm{P} \mathrm{m}^{-2}$. (Lesutiene et al. 2021). However, it is argued that the removal by biomass harvest could only be a minor factor regarding overall nutrient removal and a majority is linked to the root-associated microbial community (e.g. Wu et al. 2011; Zhu et al. 2011; Pavlineri et al. 2017). It is a challenge to measure the efficiency of floating wetlands directly as water quality measurements are often only 'snapshots' and influenced by seasonality and special events (e.g. phosphorus mobilization under low-oxygen conditions). Time series of water transparency might be a more suitable indicator than the nutrient status in the water as floating wetlands compete with phytoplankton and should reduce algae blooms in longterm. However, data on long-term water transparency progress around floating wetlands is currently lacking and should be included in future evaluations. Besides direct plant uptake, microbial transformation and sedimentation contribute significantly to nutrient removal (Wang et al. 2020). Plant roots create favorable habitats for microorganisms and this biofilm development boosts phosphorus and nitrogen removal (Haberl et al. 2003; Stottmeister et al. 2003; Wang et al. 2020). A larger root network results in the increase of surface area for biofilm development (Muench et al. 2007). Lai et al. (2012) showed that fibrous-root plants such as $L$. salicaria have not only higher photosynthesis rates and higher radial oxygen loss but also higher removal rates of total nitrogen and total phosphorus than thick-root plants. Generally, higher plant diversity presumably results in the increase of the microorganism diversity in the roots and thus improves nutrient removal efficiencies (Colares et al. 2020).

Kumwimba et al. (2020) presented different strengthening techniques how to enhance the purification performance of floating wetlands in low-temperature regions. Performance improvements can be reached inter alia by adding organic fiber fillers or inorganic functional fillers, submerged plants, external or solar-energy-driven aeration (Kumwimba et al. 2020). The authors classified the techniques into direct modifications (e.g. plant configuration) and indirect modifications (e.g. fillers or aeriation). One option that was not included but seems promising is the combination of floating wetlands with mussel cultivation to boost nutrient removal (Karstens and RazinkovasBaziukas 2019). Another aspect that should be taken into account when regarding both the habitat function and nutrient removal efficiency is the substrate that is used in constructed floating wetlands. Substrate that provides a large surface area supports and enhances biofilm development (Headley and Tanner 2006; Pavlineri et al. 2017; Bi et al. 2019). Coir mats and reed stems used in this study contribute positively to the nutrient removal efficiency. Furthermore, the reed stems inside the islands provided a refuge from predators for juvenile eels during the day time. Floating wetlands can be both valuable 'habitats' and 'nutrient buffers' at the same time. However, it is challenging to choose the best fitting native macrophyte species, the right timing for their harvest and a construction with sufficient buoyancy addressing both the habitat function and nutrient removal. Further research and testing of floating wetland designs (size, shape and material of floating construction as well as vegetation choices) regarding the ecological function in coastal environments 
would be beneficial. In our experiment, the margins of the most ecologically designed floating island were drowned. A development of sustainable and long-lasting floating constructions without artificial polymers ensuring sufficient buoyancy is the key action for further spread of these nature-based solutions.

\section{Floating wetlands as habitats in coastal waters}

The monitored floating wetland served as a resting and hunting place for grey herons (A. cinerea), mostly during sunrise hours. Besides fish, the grey heron also eats frogs, snakes and insects. Potential food items for grey herons as water frogs (R. esculenta), grass snakes ( $N$. natrix), shrimp (P. adspersus) and water scorpions (Nepa spec.) all used the floating wetlands as habitats. Other bird species were seldom spotted and the monitored floating wetland was not used as a breeding ground by any bird species. As the floating wetlands were located only $2 \mathrm{~m}$ off the coast, disturbances during daytime were common. Islands further offshore presumably would offer a more attractive spot for resting and nesting. Tall and short vegetation in coastal wetlands represent different ornithological values (Esselink et al. 2000; Wanner 2009). Coastal wetlands along the Southern Baltic coast are often dominated by tall-growing reed, which when forming continuous belts along coastline reduces the habitat biodiversity. Floating wetlands with alternate vegetation structure could offer alternative habitats, e.g. ground-nesting birds prefer short saltmarsh grasses (Esselink et al. 2000; Jutila 2001; Wanner 2009).

The floating wetlands served as refuge for numerous juvenile eels, as well as shrimp, snails, frogs and water insects. Due to the avoidance of predation as primarily nocturnal animals, eels seek dark areas rich in structure during the day or bury themselves in the sediment. This could explain the numerous findings of juvenile eels with a length of about $15 \mathrm{~cm}$. Likewise, an increased food supply in or around the swimming islands could also attract juvenile eels. The relatively high density of juvenile eels (about 2.1 per $\mathrm{m}^{2}$ ) inside the floating wetlands is remarkable given the general state of the eel stock in the Southern Baltic Sea and the coastal inlets. Current assumption is that eel recruitment in the North and Baltic Seas is less than 5\% of that before 1980 (ICES 2018). However, during the last years there has been a slight recovery in recruitment (ICES 2018), which should also result in the increase in the eel stock in the coastal waters of the study area. Our observations are consistent with this assumption. Bi et al. (2019) showed that floating wetlands improve ecosystem conditions and lead to more diverse fish and invertebrate communities. They provide shelter as well as food sources (Wang et al. 2015). Huang et al. (2017) observed a three times greater nekton abundance around artificial floating wetlands and Wang et al. (2015) discovered that aquatic macroinvertebrates and tadpoles inhibited floating mats. Phytoplankton and bacteria create a biofilm on the macrophyte roots which does not only contribute to denitrification, but also serve as food for zooplankton and fish (Cazzanelli et al. 2008; Henninger et al. 2009; Pang et al. 2016; Srivastava et al. 2017; Yan et al. 2018).

\section{Conclusions}

Eutrophication remains an environmental challenge in lagoons along the Southern Baltic Sea and floating islands planted with emergent macrophytes are an option to remove excess nutrients. Usually artificial polymers are used to construct floating treatment wetlands. In this study a plastic free floating construction made out of locally grown plant material (dry reed stems) was tested revealing the need of technological improvement primarily related to the long-lasting buoyancy. The chosen macrophyte species managed to cope with the fluctuating salinities and showed the potential to create 'biodiversity-supplements' as adjacent wetlands along the Southern Baltic Sea are usually dominated by reed.. I. pseudacorus, an endangered species, had the highest nitrogen concentrations, while $L$. salicaria, a fibrous-root plant, had the highest phosphorus concentrations. Species diversity and a large rhizome network enhance biofilm development and thus nutrient removal capacity. A diverse root network benefits not only nutrient removal capacity but serves also as a shelter and retreat for aquatic fauna. The islands were notably used by juvenile eels and shrimps as a refuge from predators. The relatively high density of juvenile eels (about 2.1 per $\mathrm{m}^{2}$ ) is remarkable given the general state of the eel stock in the Southern Baltic Sea and the coastal inlets. Furthermore, the floating wetlands served as a resting and hunting place for grey herons (A. cinerea) and provided habitats for other birds, amphibians, crustacean, molluscs and insects. Floating wetlands in coastal environments can be used as 'biodiversity rich habitats' as well as 'nutrient buffers', however, decision-makers have to weigh inter alia the island design, choice of construction material, macrophyte species as well as harvest timing, depending on the local management goals. 


\section{Appendix}

Table 5 Animal observations. Continuous video monitoring was applied between the 31st of May 2018 and the 6th of September 2018. In addition, field observations were carried out on the 6th of September 2018 (in grey)

\begin{tabular}{|c|c|c|c|}
\hline Date & Time & Species (english) & Species (latin) \\
\hline 26.06 .2018 & $8: 42-9: 12$ & Gray Heron & Ardea cinerea \\
\hline 26.06.2018 & $9: 32$ & Gray Heron & Ardea cinerea \\
\hline 26.06.2018 & $18: 22$ & Blackbird & Turdus merula \\
\hline 27.06.2018 & $3: 58-5: 38$ & Gray Heron & Ardea cinerea \\
\hline 28.06.2018 & $4: 49-4: 59$ & Gray Heron & Ardea cinerea \\
\hline 03.07.2018 & $3: 46$ & Gray Heron & Ardea cinerea \\
\hline 03.07.2018 & $9: 34$ & Black-headed Gull & Chroicocephalus ridibundus \\
\hline 04.07.2018 & 4:45 & Gray Heron & Ardea cinerea \\
\hline 05.07.2018 & $3: 16-5: 46$ & Gray Heron & Ardea cinerea \\
\hline 05.07.2018 & $6: 46$ & Gray Heron & Ardea cinerea \\
\hline 05.07.2018 & $17: 56-19: 46$ & Gray Heron & Ardea cinerea \\
\hline 06.07 .2018 & $03: 27-06: 47$ & Gray Heron & Ardea cinerea \\
\hline 07.07.2018 & $03: 11-04: 31$ & Gray Heron & Ardea cinerea \\
\hline 08.07.2018 & $5: 07$ & Gray Heron & Ardea cinerea \\
\hline 08.07.2018 & 03:07-03:47 & Gray Heron & Ardea cinerea \\
\hline 08.07.2018 & 03:57-06:47 & Gray Heron & Ardea cinerea \\
\hline 09.07.2018 & $3: 13-4: 53$ & Gray Heron & Ardea cinerea \\
\hline 09.07.2018 & $18: 23-18: 43$ & Gray Heron & Ardea cinerea \\
\hline 10.07.2018 & $3: 24$ & Gray Heron & Ardea cinerea \\
\hline 10.07.2018 & $3: 54-4: 24$ & Gray Heron & Ardea cinerea \\
\hline 10.07.2018 & $5: 14$ & Gray Heron & Ardea cinerea \\
\hline 11.07.2018 & 03:25-04:05 & Gray Heron & Ardea cinerea \\
\hline 12.07.2018 & $05: 25-06: 15$ & Gray Heron & Ardea cinerea \\
\hline 12.07.2018 & $3: 41-5: 11$ & Gray Heron & Ardea cinerea \\
\hline 13.07.2018 & 03:16-05:06 & Gray Heron & Ardea cinerea \\
\hline 14.07.2018 & $03: 17-05: 27$ & Gray Heron & Ardea cinerea \\
\hline 14.07.2018 & $06: 47-06: 57$ & Mallard & Anas platyrhynchos \\
\hline 15.07.2018 & 03:23-06:33 & Gray Heron & Ardea cinerea \\
\hline 15.07.2018 & $20: 43-21: 03$ & Gray Heron & Ardea cinerea \\
\hline 17.07.2018 & $4: 25$ & Gray Heron & Ardea cinerea \\
\hline 17.07.2018 & $5: 05-6: 35$ & Gray Heron & Ardea cinerea \\
\hline 18.07.2018 & 03:40-04:50 & Gray Heron & Ardea cinerea \\
\hline 19.07.2018 & $3: 31-4: 21$ & Gray Heron & Ardea cinerea \\
\hline 22.07.2018 & $03: 44-04: 14$ & Gray Heron & Ardea cinerea \\
\hline 22.07.2018 & 06:04-06:34 & Gray Heron & Ardea cinerea \\
\hline 23.07 .2018 & $3: 35-5: 15$ & Gray Heron & Ardea cinerea \\
\hline 23.07.2018 & $7: 25$ & Sparrow & Passer indet. \\
\hline 23.07.2018 & $10: 45$ & Sparrow & Passer indet. \\
\hline 24.07.2018 & $3: 41$ & Gray Heron & Ardea cinerea \\
\hline 25.07.2018 & 04:29-05:09 & Gray Heron & Ardea cinerea \\
\hline 26.07.2018 & $3: 40-4: 00$ & Gray Heron & Ardea cinerea \\
\hline 27.07.2018 & $11: 01$ & Grass snake & Natrix natrix \\
\hline 27.07.2018 & 03:40-04:00 & Gray Heron & Ardea cinerea \\
\hline 28.07.2018 & 04:12-06:02 & Gray Heron & Ardea cinerea \\
\hline 29.07.2018 & $19: 42-20: 32$ & Gray Heron & Ardea cinerea \\
\hline 29.07.2018 & 03:48-03:58 & Gray Heron & Ardea cinerea \\
\hline 29.07.2018 & 04:08-04:48 & Gray Heron & Ardea cinerea \\
\hline 29.07.2018 & 05:18-05:38 & Gray Heron & Ardea cinerea \\
\hline 29.07.2018 & $06: 18-06: 58$ & Gray Heron & Ardea cinerea \\
\hline 29.07.2018 & 07:18-07:38 & Gray Heron & Ardea cinerea \\
\hline 29.07.2018 & $11: 08-11: 28$ & Gray Heron & Ardea cinerea \\
\hline 30.07 .2018 & $3: 55$ & Gray Heron & Ardea cinerea \\
\hline 30.07 .2018 & $5: 15-5: 25$ & Gray Heron & Ardea cinerea \\
\hline 31.07.2018 & $4: 21-4: 41$ & Gray Heron & Ardea cinerea \\
\hline 02.08 .2018 & $3: 59-4: 29$ & Gray Heron & Ardea cinerea \\
\hline 02.08 .2018 & 4:59-5:09 & Gray Heron & Ardea cinerea \\
\hline 03.08 .2018 & 03:55-04:35 & Gray Heron & Ardea cinerea \\
\hline 04.08 .2018 & $14: 12-14: 32$ & Water Frog & Rana esculenta \\
\hline 06.08 .2018 & $20: 34$ & Gray Heron & Ardea cinerea \\
\hline 10.08.2018 & 04:21-04:31 & Gray Heron & Ardea cinerea \\
\hline 10.08.2018 & 06:01-06:11 & Gray Heron & Ardea cinerea \\
\hline 15.08.2018 & $9: 03$ & Black-headed Gull & Chroicocephalus ridibundus \\
\hline 18.08 .2018 & $06: 22-07: 52$ & Gray Heron & Ardea cinerea \\
\hline 19.08 .2018 & $4: 24$ & Gray Heron & Ardea cinerea \\
\hline 19.08 .2018 & $4: 54-5: 24$ & Gray Heron & Ardea cinerea \\
\hline 19.08.2018 & $7: 44-7: 54$ & Gray Heron & Ardea cinerea \\
\hline 20.08.2018 & $5: 05-5: 15$ & Gray Heron & Ardea cinerea \\
\hline 24.08.2018 & $4: 39$ & Gray Heron & Ardea cinerea \\
\hline 25.08.2018 & $13: 11$ & Gray Heron & Ardea cinerea \\
\hline 29.08.2018 & $5: 02$ & Gray Heron & Ardea cinerea \\
\hline 31.08 .2018 & $4: 56$ & Gray Heron & Ardea cinerea \\
\hline 31.08 .2018 & $6: 56$ & Gray Heron & Ardea cinerea \\
\hline 01.09 .2018 & $7: 59$ & Gray Heron & Ardea cinerea \\
\hline 06.09 .2018 & & Eels & Anguilla anguilla \\
\hline 06.09 .2018 & & Shrimps & Palaemon adspersus \\
\hline 06.09 .2018 & & Water scorpions & Nepa $s p$ \\
\hline 06.09 .2018 & & Crabs & Rhithropanopeus harrisii \\
\hline 06.09 .2018 & & Snails & Gastropoda indet \\
\hline
\end{tabular}


Authors' contributions SK developed the article concept, took care of the data analyses and did most of the article writing. ML, HN, IC supported the data collection, analysis of continuous video monitoring and commented on the paper. ARB and NS supported the analysis and commented on the paper. RB supported the article concept development, the writing and the analysis.

Funding This research is part of following projects: (1) 'The use of active barriers for the nutrient removal and local water quality improvement in Baltic lagoons (LiveLagoons)', funded by EU South Baltic Interreg Program (STHB.02.02.00-LT-0089/16). (2) "Innovationsraum: BaMS-HaFF - Halophyten und andere Makrophyten zur Filtration von nährstoffbelasteten $\mathrm{Ab}$ - und Oberflächenwasser in Freilandkultur" (FKZ031B0915C2), funded by the German Federal Ministry of Education and Research.

Data availability All datasets generated for this study are included in the manuscript and appendix.

\section{Declarations}

Conflict of interest The authors declare that they have no known competing financial interests or personal relationships that could have appeared to influence the work reported in this paper.

Open Access This article is licensed under a Creative Commons Attribution 4.0 International License, which permits use, sharing, adaptation, distribution and reproduction in any medium or format, as long as you give appropriate credit to the original author(s) and the source, provide a link to the Creative Commons licence, and indicate if changes were made. The images or other third party material in this article are included in the article's Creative Commons licence, unless indicated otherwise in a credit line to the material. If material is not included in the article's Creative Commons licence and your intended use is not permitted by statutory regulation or exceeds the permitted use, you will need to obtain permission directly from the copyright holder. To view a copy of this licence, visit http://creativecommons. org/licenses/by/4.0/.

\section{References}

Afzal M, Arslan M, Müller JA, Shabir G, Islam E, Tahseen R, ..., Khan QM (2019) Floating treatment wetlands as a suitable option for large-scale wastewater treatment. Nature Sustain, 2 (9), 863-871

Berthold M, Schumann R (2020) Phosphorus dynamics in a eutrophic lagoon: uptake and utilization of nutrient pulses by phytoplankton. Front Mar Sci 7:1-15

Berthold M, Karstens S, Buczko U, Schumann R (2018) Potential export of soluble reactive phosphorus from a coastal wetland in a cold-temperate lagoon system: buffer capacities of macrophytes and impact on phytoplankton. Sci Total Environ 616-617:46-54

Bi R, Zhou C, Jia Y, Wang S, Li P, Reichwaldt ES, Liu W (2019) Giving waterbodies the treatment they need: a critical review of the application of constructed floating wetlands. J Environ Manag 238:484-498

Borne K (2013) Stormwater quality treatment and pollutant removal pathways by a floating treatment wetland. http://hdl.handle.net/ 2292/21002. Accessed 2020/09/10
Bower CE, Holm-Hansen T (1980) A salicylate-hypochlorite method for determining ammonia in seawater. Can J Fish Aquat Sci 37(5):794e798

Bu F, Xu X (2013) Planted floating bed performance in treatment of eutrophic river water. Environ Monit Assess 185(11):9651-9662

Burnside NG, Joyce CB, Puurmann E, Scott DM (2007) Use of vegetation classification and plant indicators to assess grazing abandonment in Estonian coastal wetlands. J Veg Sci 18(5):645-654

Cao W, Wang Y, Sun L, Jiang J, Zhang Y (2016) Removal of nitrogenous compounds from polluted river water by floating constructed wetlands using rice straw and ceramsite as substrates under low temperature conditions. Ecol Eng 88:77-81

Cazzanelli M, Warming PT, Christoffersen SK (2008) Emergent and floating-leaved macrophytes as refuge for zooplankton in an eutrophic temperate lake without submerged vegetation. Hydrobiologia 605:113-122

Chambers RM, Meyerson LA, Saltonstall K (1999) Expansion of Phragmites australis into tidal wetlands of North America. Aquat Bot 64(3-4):261-273

Chang NB, Islam MK, Wanielista MP (2012) Floating wetland mesocosm assessment of nutrient removal to reduce ecotoxicity in stormwater ponds. Int J Environ Sci Technol 9(3):453-462

Choudhury MI, Segersten J, Hellman M, Mckie BG, Hallin S, Ecke F (2019) Importance of plant species for nitrogen removal using constructed floating wetlands in a cold climate. Ecol Eng 138:126-132

Colares GS, Dell' Osbel N, Wiesel PG, Oliveira GA, Lemos PHZ, da Silva FP et al (2020) Floating treatment wetlands: a review and bibliometric analysis. Sci Total Environ 714:136776

Conley DJ, Carstensen J, Aigars J, Axe P, Bonsdorff E, Eremina T et al (2011) Hypoxia is increasing in the coastal zone of the Baltic Sea. Environ Sci Technol 45(16):6777-6783

DeSorbo CR, Fair J, Taylor K, Hanson W, Evers DC, Vogel HS, Cooley JH (2008) Guidelines for constructing and deploying common loon nesting rafts. Northeast Nat 15(1):75-86

Ellenberg H, Leuschner C (2010) Vegetation Mitteleuropas mit den Alpen.. Utb

Esselink P, Zijlstra W, Dijkema KS, Van Diggelen R (2000) The effects of decreased management on plant species distribution patterns in a salt-marsh nature reserve in the Wadden Sea. Biol Conserv 93:61-76

Geng Y, Han W, Yu C, Jiang Q, Wu J, Chang J, Ge Y (2017) Effect of plant diversity on phosphorus removal in hydroponic microcosms simulating floating constructed wetlands. Ecol Eng 107:110-119

Grasshoff K, Ehrhardt M, Kremling K (1983) Methods of seawater analysis, 2nd edn. Verlag Berlin Chemie

Haberl R, Grego S, Langergraber G, Kadlec RH, Cicalini AR, Dias SM et al (2003) Constructed wetlands for the treatment of organic pollutants. J Soils Sediments 3(2):109

Hancock M (2000) Artificial islands for nesting black-throated divers Gavis arctica in Scotland: construction use and effect on breeding success. Bird Study 47:165-175

Headley T, Tanner CC (2006) Application of floating wetlands for enhanced stormwater treatment: a review. Auckland Regional Council, New Zealand. http://www.aucklandcity.govt.nz/counc il/documents/technicalpublications/TP324\%20-\%20Floating\% 20Wetland\%20Review-Final.pdf. Accessed 2020/09/10

Henninger TO, Froneman PW, Richoux NB, Hodgson AN (2009) The role of macrophytes as a refuge and food source for the estuarine isopod Exosphaeroma hylocoetes. Estuar Coast Shelf Sci 82(2):285-293

Hernández-Crespo C, Oliver N, Bixquert J, Gargallo S, Martín M (2016) Comparison of three plants in a surface flow constructed 
wetland treating eutrophic water in a Mediterranean climate. Hydrobiologia 774(1):183-192

Huang X, Zhao F, Song C, Gao Y, Geng Z, Zhuang P (2017) Effect of stereoscopic artificial floating wetlands on nekton abundance and biomass in the Yangtze estuary. Chemosphere 183:510-518

Hupfer P (2010) Die Ostsee - kleines Meer mit großen Problemen. Borntraeger, Stuttgart

ICES (2018) Report of the Joint EIFAAC/ICES/GFCM Working Group on Eels (WGEEL), 5-12 September 2018, Gdańsk, Poland. ICES CM 2018/ACOM:15. 152 pp

Jeschke L (1987) Vegetationsdynamik des Salzgraslandes im Bereich der Ostseeküste der DDR unter Einfluß des menschen (anthropic vegetation dynamics of salt grasslands at the Baltic Sea shore of the GDR). Hercynia 24:321-328

Jutila $H$ (2001) How does grazing by cattle modify the vegetation of coastal grassland along the Baltic Sea? Ann Bot Fenn 38:181-200

Karstens S, Razinkovas-Baziukas A (2019) Floating wetlands in combination with mussel cultivation to boost nutrient removal. Coast Mar 28(1):16-17

Karstens S, Nazzari C, Bâlon C, Bielecka M, Grigaitis Ž, Schumacher J, ..., Razinkovas-Baziukas A (2018) Floating wetlands for nutrient removal in eutrophicated coastal lagoons: Decision support for site selection and permit process. Mar Policy 97: 51-60

Karstens S, Inácio M, Schernewski G (2019) Expert-based evaluation of ecosystem service provision in coastal reed wetlands under different management regimes. Front Environ Sci 7:63

Kautsky L, Kautsky N (2000) The Baltic Sea, including Bothnian Sea and Bothnian Bay. Seas at the Millenium: An Environmental Evaluation, Volume 1, Regional Seas: Europe, The Americas and West Africa, Elsevier Science Ltd., Oxford (UK) and Pergamon Press, Amsterdam, 121-133

Keizer-Vlek HE, Verdonschot PF, Verdonschot RC, Dekkers D (2014) The contribution of plant uptake to nutrient removal by floating treatment wetlands. Ecol Eng 73:684-690

Koroleff F (1983) Determination of phosphorus. In: Grasshoff K, Ehrhardt M, Kremling K (Eds.), Methods of Seawater Analysis, 2nd edn. Verlag Chemie, pp. 125-132

Kumwimba MN, Batool A, Li X (2020) How to enhance the purification performance of traditional floating treatment wetlands (FTWs) at low temperatures: strengthening strategies. Sci Total Environ 142608

Lai W, Zhang Y, Chen Z (2012) Radial oxygen loss, photosynthesis, and nutrient removal of 35 wetland plants. Ecol Eng 39:24-30

Lesutienè J, Bielecka M, Grigaitis Ž, Stybel N, Karstens S, RazinkovasBaziukas A (2021) (in preparation). Floating wetland commercialization guide. Technical Report LiveLagoons project. http:// www.balticlagoons.net/livelagoons

Muench C, Neu T, Kuschk P, Roeske I (2007) The root surface as the definitive detail for microbial transformation processes in constructed wetlands - a biofilm characteristic. Water Sci Technol 56:271-276

Nakamura K, Tsukidate M, Shimatani Y (1998) Characteristic of ecosystem of an artificial vegetated floating island. In: Uso, J.L., Brebbia, C.A., Power, H. (Eds.), Ecosystems and Sustainable Development, pp. 171-181

Newton A, Icely J, Cristina S, Brito A, Cardoso AC, Colijn F et al (2014) An overview of ecological status, vulnerability and future perspectives of European large shallow, semi-enclosed coastal systems, lagoons and transitional waters. Estuar Coast Shelf Sci 140:95-122

Nummi P, Vaananen VM, Pakarinen R, Pienmunne E (2013) The redthroated diver (Gavia stellate) in human-disturbed habitats-building up a local population with the aid of artificial rafts. Ornis Fennica 90:16-22

Olguín EJ, Sánchez-Galván G, Melo FJ, Hernández VJ, GonzálezPortela RE (2017) Long-term assessment at field scale of floating treatment wetlands for improvement of water quality and provision of ecosystem services in a eutrophic urban pond. Sci Total Environ 584-585:561-571

Overton TC, Takekawa YJ, Casazza ML, Bui DT, Holyoak M, Strong RD (2015) Sea-level rise and refuge habitats for tidal marsh species: can artificial island save the California Ridgeway's rail? Ecol Eng 74:337-344

Pang S, Zhang S, Lv X, Han B, Liu K, Qiu C, Wang C, Wang P, Toland H, He Z (2016) Characterization of bacterial community in biofilm and sediments of wetlands dominated by aquatic macrophytes. Ecol Eng 97:242-250

Pavlineri N, Skoulikidis NT, Tsihrintzis VA (2017) Constructed floating wetlands: a review of research, design, operation and management aspects, and data meta-analysis. Chem Eng J 308:1120-1132

Prach K, Pyšek P (1994) Clonal plants-what is their role in succession? Folia Geobot. Phytotaxonimica 29:307-320

Qiu ZC, Wang M, Lai WL, He FH, Chen ZH (2011) Plant growth and nutrient removal in constructed monoculture and mixed wetlands related to stubble attributes. Hydrobiologia 661(1):251-260

Rannap R, Briggs L, Lotman K, Lepik I, Rannap V (2004) Coastal meadow management. Ministry of the Environment of the Republic of Estonia. Tallinn. https://www.keskkonnaamet.ee/sites/defau 1t/public/documents/trykised/coastal_meadow_management.PDF. Accessed 2020/09/10

Sanicola O, Lucke T, Stewart M, Tondera K, Walker C (2019) Root and shoot biomass growth of constructed floating wetlands plants in saline environments. Int J Environ Res Public Health 16(2):275

Schumann R, Baudler H, Glass Ä, Dümcke K, Karsten U (2006) Longterm observations on salinity dynamics in a tideless shallow coastal lagoon of the southern Baltic Sea coast and their biological relevance. J Mar Syst 60(3-4):330-344

Selig U, Schubert M, Eggert A, Steinhardt T, Sagert S, Schubert H (2007) The influence of sediments on soft bottom vegetation in inner coastal waters of Mecklenburg-Vorpommern (Germany). Estuar Coast Shelf Sci 71:241-249

Shealer DA, Buzzell JM, Heiar JP (2006) Effect of floating nest platforms on the breeding performance of black terns. J Field Ornithol 77(2):184-194

Srivastava KJ, Chandra H, Kalra SJ, Mishra P, Khan H, Yadav P (2017) Plant-microbe interaction in aquatic system and their role in the management of water quality: a review. Appl Water Sci 7:1079-1090

Stottmeister U, Wießner A, Kuschk P, Kappelmeyer U, Kästner M, Bederski $\mathrm{O}$ et al (2003) Effects of plants and microorganisms in constructed wetlands for wastewater treatment. Biotechnol Adv 22(1-2):93-117

Sweers W, Horn S, Grenzdörffer G, Müller J (2013) Regulation of reed (Phragmites australis) by water buffalo grazing: use in coastal conservation. Mires Peat 13:1-10. Available online at: http:// mires-and-peat.net/media/map13/map_13_03.pdf. Accessed 2020/09/10

Vybernaite-Lubiene I, Zilius M, Giordani G, Petkuviene J, Vaiciute D, Bukaveckas PA, Bartoli M (2017) Effect of algal blooms on retention of N, Si and P in Europe's largest coastal lagoon. Estuar Coast Shelf Sci 194:217-228

Wang CY, Sample DJ, Day SD, Grizzard TJ (2015) Floating treatment wetland nutrient removal through vegetation harvest and observations from a field study. Ecol Eng 78:15-26

Wang WH, Wang Y, Sun LQ, Zheng YC, Zhao JC (2020) Research and application status of ecological floating bed in eutrophic landscape water restoration. Sci Total Environ 704:135434

Wanner A (2009) Management, biodiversity and restoration potential of salt grassland vegetation of the Baltic Sea: Analyses along a complex ecological gradient. PhD Thesis, Universität Hamburg, Hamburg, $221 \mathrm{pp}$ 
West M, Fenner N, Gough R, Freeman C (2017) Evaluation of algal bloom mitigation and nutrient removal in floating constructed wetlands with different macrophyte species. Ecol Eng

White SA, Cousins MM (2013) Floating treatment wetland aided remediation of nitrogen and phosphorus from simulated stormwater runoff. Ecol Eng 61:207-215

Wu H, Zhang J, Li P, Zhang J, Xie H, Zhang B (2011) Nutrient removal in constructed microcosm wetlands for treating polluted river water in northern China. Ecol Eng 37(4):560-568

Yan L, Zhang S, Lin D, Guo C, Yan L, Wang S, He Z (2018) Nitrogen loading affects microbes, nitrifiers and denitrifiers attached to submerged macrophyte in constructed wetlands. Sci Total Environ 622-623:121-126
Yeh N, Yeh P, Chang Y-H (2015) Artificial floating islands for environmental improvement. Renew Sust Energ Rev 47:616-622

Zhang CB, Wang J, Liu WL, Zhu SX, Ge HL, Chang SX, Chang J, Ge Y (2010) Effects of plant diversity on microbial biomass and community metabolic profiles in a full-scale constructed wetland. Ecol Eng 36:62-68

Zhu L, Li Z, Ketola T (2011) Biomass accumulations and nutrient uptake of plants cultivated on artificial floating beds in China's rural area. Ecol Eng 37(10):1460-1466

Publisher's note Springer Nature remains neutral with regard to jurisdictional claims in published maps and institutional affiliations. 